\title{
Wetlands in Brazil: classification, floristic composition and biological Nitrogen
}

\author{
fixation \\ Áreas Úmidas no Brasil: classificação, composição florística e fixação biológica de Nitrogênio \\ Humedales en Brasil: clasificación, composición florística y fijación biológica de Nitrógeno
}

\begin{abstract}
Wetland ecosystems represent about $20 \%$ of South America, and are classified according to the flood regime, which also influences on vegetation. Despite the value of ecosystem services provided by this environment, those areas are close to eradication in several parts of Brazil. These environments are extremely fragile. Flooded areas are subject to nitrogen losses $(\mathrm{N})$ by leaching, becoming dependent on the $\mathrm{N}$ increases from biological nitrogen fixation (BNF). However, little is known about this process on wetlands. Understanding the adaptative strategies of these microorganisms and plants is essential for the maintenance and preservation of these ecosystems. The objective of this work is to present a literature review discussing aspects of floristic composition, biological nitrogen fixation, and morphophysiological adaptations that occur in the rhizobium-leguminous system in wetlands. For the bibliographic survey, articles and other academic works relevant to the topic were selected, in order to enrich the proposed
\end{abstract} discussion.

Keywords: Adaptative strategies; Flooded areas; Legume; Nitrogen-fixing bacteria.

\section{Resumo}

Os sistemas alagados representam cerca de $20 \%$ da área da América do sul, sendo classificados de acordo com o regime de inundação, o que também influencia na vegetação. Apesar da importância dos serviços ecossistêmicos prestados por esses ambientes, essas áreas encontram-se próximas da erradicação em várias partes do Brasil. Esses ambientes são extremamente frágeis. As áreas alagadas estão sujeitas a perdas de nitrogênio $(\mathrm{N})$ por lixiviação, tornando-se então, dependentes de acréscimos de $\mathrm{N}$ proporcionados pela fixação biológica de nitrogênio (FBN). No entanto, pouco se sabe sobre esse processo nas áreas úmidas. Entender as estratégias adaptativas desses microrganismos e das plantas é essencial para a manutenção e preservação desses ecossistemas. O objetivo do trabalho é apresentar uma revisão de literatura discutindo os aspectos de composição florística, fixação biológica de nitrogênio e adaptações morfofisiológicas que ocorrem no sistema rizóbios-leguminosas em áreas úmidas. Para o levantamento bibliográfico foram selecionados artigos e demais trabalhos acadêmicos pertinentes ao tema, de forma a enriquecer a discussão proposta.

Palavras-chave: Áreas alagadas; Bactérias fixadoras de nitrogênio; Estratégias adaptativas; Leguminosas.

\section{Resumen}

Los sistemas inundables representan cerca del 20\% del área de América del Sur, clasificándose según el régimen de inundación, que también influye en la vegetación. A pesar de la importancia de los servicios ecosistémicos proporcionados por estos ambientes, estas áreas están cerca de la erradicación en varias partes de Brasil. Estos entornos son extremadamente frágiles. Los humedales están sujetos a pérdidas de nitrógeno $(\mathrm{N})$ por lixiviación, por lo que se vuelven dependientes de las adiciones de $\mathrm{N}$ proporcionadas por la fijación biológica de nitrógeno (BNF). Sin embargo, poco se sabe sobre este proceso en los humedales. Comprender las estrategias adaptativas de estos microorganismos y plantas es esencial para el mantenimiento y preservación de estos ecosistemas. El objetivo de este trabajo es presentar una revisión de literatura discutiendo aspectos de composición florística, fijación biológica de 
nitrógeno y adaptaciones morfofisiológicas que ocurren en el sistema rizobio-leguminosas en humedales. Para el levantamiento bibliográfico, se seleccionaron artículos y otros trabajos académicos relevantes al tema, con el fin de enriquecer la discusión propuesta.

Palabras clave: Áreas inundadas; Bacterias fijadoras de nitrógeno; Estrategias adaptativas; Legumbres.

\section{Introduction}

Wetland ecosystems involve all forms of flooded soils with vegetation, such as swamps, marshes, and mangroves (Mitsch \& Gosselink, 2000). In South America, it is estimated that $20 \%$ of the total area is subject to flooding during periods of excessive rain. According to Costanza et al. (2014), the value of ecosystem services provided per unit area is 10-100 fold higher in wetlands when compared to dryland, making the understanding of the functioning of these areas vital (Neori \& Agami, 2017)

The vegetation that occurs in these places can be classified, according to the flood regime, in alluvial and swamp forests (Silva et al., 2007), according to them, little is known about the species distribution patterns in flooded ecosystems, however, Marques et al. (2003), point out that, as they present a more selective, homogeneous and stable environment, swamp forests tend to have fewer species.

Despite their great importance as regulators of erosion processes, stabilization of margins, and promotion of nutrient cycling, the areas subject to flooding (permanent or temporary) are close to eradication in several parts of Brazil. These environments are extremely fragile and tend to have acidic soils, with slow drainage and high levels of organic matter, mainly due to the reduction in microbial activity caused by the absence or low concentration of oxygen.

Flooded areas are subject to nitrogen losses $(\mathrm{N})$ by leaching, becoming dependent on the $\mathrm{N}$ increases from biological nitrogen fixation (BNF), where the rhizobium-leguminous association is the main contributor (Loureiro et al., 1998). However, legumes are, mainly, sensitive to flooding, producing additional mechanisms to increase the oxygen supply, making it possible to maintain the BNF process.

Little is known about BNF and nodular diazotrophic bacteria colonizing plant species from tropical forests (Cassetari, 2011). Krishnam et al. (2019), observed the formation of nodules in Sesbania herbacea (Mill.) under flooding conditions, the authors reported that flooding increases the number of nodules on Sesbania roots, and a BLAST analysis revealed a $100 \%$ sequence homology to $16 \mathrm{~S}$ ribosomal RNA of Neorhizobium huautlense. Another studied by Brasil et al. (2016) about the influence of flood areas on the number of diazotrophic bacteria from pasture grasses showed that the presence of Azospirillum and Herbaspirillum presented high number in grasses Hymenachne amplexicaulis of permanent flood areas. Understanding the strategies used to increase the availability of $\mathrm{N}$ in flooded soils is essential for the maintenance and preservation of these ecosystems. The objective of this work is to present a literature review discussing aspects of floristic composition, biological nitrogen fixation, and morphophysiological adaptations that occur in the rhizobium-leguminous system in wetlands.

\section{Methodology}

In order to achieve the objectives, a systematic review was done. A systematic review is important because allows different points of view of the same subject. In addition, the use of this methodology identifies gaps in the literature, providing trustworthy data for future studies. The data collection followed four steps: planning, research, sorting, and analysis of the content (Figure 1). Three data bases were used in this study: Scielo, Scopus, and Google Scholar, using the index terms: wetlands in Brazil, rhizobium, sustainability, and floristic composition. 
Figure 1 - Research protocol.

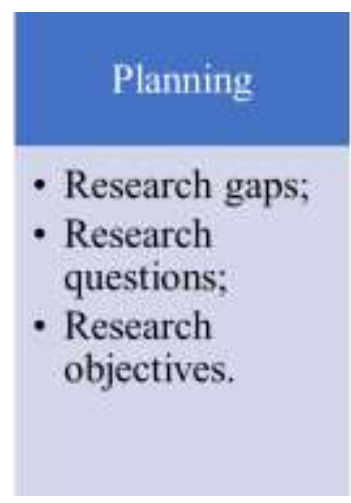

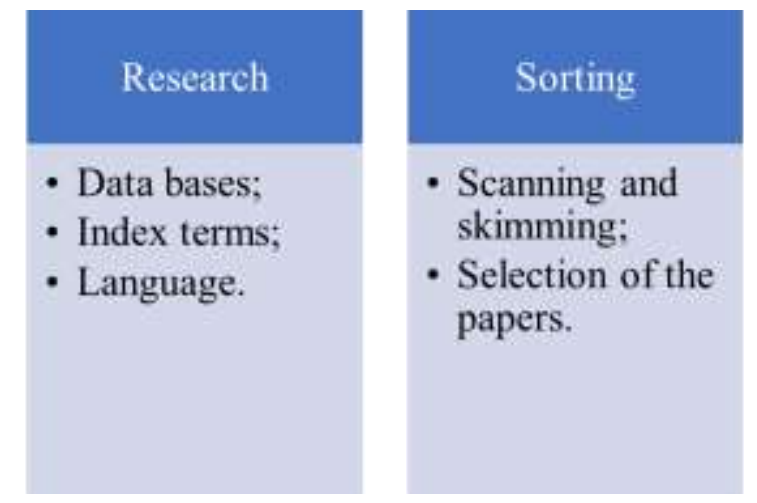

Source: Authors (2022).

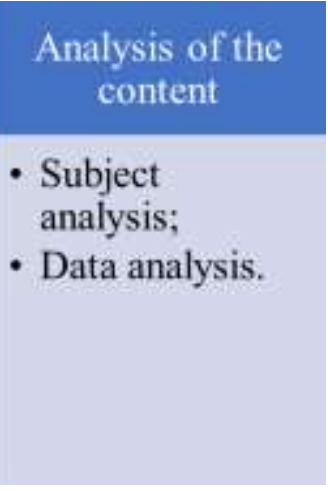

The inclusion criteria were based on the relevance of the paper for the research, as well as the language, selecting only paper in English or Portuguese. However, as exclusion criteria it was excluded the papers with a lot of similarity, being chosen those published most recently. Also, to select the papers, first it was reviewed the titles and abstracts, and articles that did not meet the objectives of the present study were excluded. Then, the full text of the articles previously selected was read, and if there was lack of relevant information, the paper was excluded.

Scanning and Skimming were the techniques used to read and select the texts. Skimming allows the reader to get a general overview of the material, and Scanning, on the other hand, permits to find specific information. Finally, once the papers were selected, the analysis of the content was done to summarize the main ideas, to fulfill the gaps, and answer the questions to achieve the literature review objectives.

\section{Results and Discussion}

\section{Wetlands in Brazil}

Wetlands cover approximately $20 \%$ of the Brazilian territory (Junk et al., 2015), and more than $90 \%$ are in the interior of the country, as a result of high precipitation and flat relief. In 1971, the first international wetland convention was held in Ramsar, Iran, which is characterized by being the first worldwide meeting related to the enhancement of these environments (Siman Gomes \& Magalhaes Júnior, 2018)

In 1993, Brazil became a member of the Ramsar convention, becoming responsible for surveying, classifying, and promoting management and conservation studies in its wetlands. However, little progress was noted in the application of these criteria, making, according to the National Institute of Wetlands (INAU), the ecological and environmental functions of these Brazilian ecosystems little known and undervalued in legal and socio-political terms.

Due to its territorial extension, Brazil has a wide variety of wetlands, according to Junk (2011), the heterogeneity is related to variations in the rainfall regime, creating a mosaic of different types of wetlands. Junk et al. (2015) indicate that there are about 111 terminologies found in the Brazilian legal system. Table 1 shows those that stand out according to the author. 
Table 1: Popular names for the different types of Brazilian wetlands and their characterization.

\begin{tabular}{|c|c|c|}
\hline Popular name & Region & Characterization \\
\hline Baixada litorânea (Restinga) & Coastal area & $\begin{array}{l}\text { Bodies of shallow water and swamps between dunes on the } \\
\text { coast, outcropping groundwater, with aquatic and palustres } \\
\text { macrophytes, even forested. }\end{array}$ \\
\hline Banhado & South of Brazil & General designation of wetlands in Rio Grande do Sul. \\
\hline Branquilhal/ Brejo & Paraná & $\begin{array}{l}\text { Lowland forest. A little specific name for waterlogged } \\
\text { areas. }\end{array}$ \\
\hline Buritizal & Brazil & Soaked areas covered with buritis (Mauritia flexuosa). \\
\hline Campina/Campinarama & Central Amazon & $\begin{array}{l}\text { Sandy areas with periodically soaked soils, covered by } \\
\text { hydromorphic savanna vegetation. }\end{array}$ \\
\hline Carnaubal & Coastal area & $\begin{array}{l}\text { Fresh water-soaked areas, dominated by the Carnaúba palm } \\
\text { (Copernicia prunifera) and palm trees }\end{array}$ \\
\hline Caxetal & Southeast/ south & $\begin{array}{l}\text { Peat / muddy forest with the dominance of Tabebuia } \\
\text { cassinoides Lam. }\end{array}$ \\
\hline Chavascal & Amazon & $\begin{array}{l}\text { Permanently soaked area, covered with highly flood } \\
\text { resistant forest }\end{array}$ \\
\hline Estuário & Brazil & $\begin{array}{l}\text { Coastal wetlands characterized as the final areas of rivers or } \\
\text { lakes with strong influence of tides and saline water. }\end{array}$ \\
\hline Igapó & Central Amazon & $\begin{array}{l}\text { Floodable area along rivers of black and clear water, poor } \\
\text { in nutrients. }\end{array}$ \\
\hline Lagoa & Brazil & $\begin{array}{l}\text { Permanent or temporary bodies of water throughout the } \\
\text { national territory. }\end{array}$ \\
\hline Laguna Costeira & Coastal area & $\begin{array}{l}\text { Bodies of water along the coast, usually of salinity and } \\
\text { vegetation variable. }\end{array}$ \\
\hline Lavrados & Roraima & $\begin{array}{l}\text { Savannah areas with lakes, swamps and footpaths } \\
\text { dominated by Mauritia flexuosa. }\end{array}$ \\
\hline Manguezal & Coastal area & $\begin{array}{l}\text { Coastal ecosystem, which occupies muddy, clayey or sandy } \\
\text { sedimentary deposits up to the upper limit of the equinocial } \\
\text { high tides. }\end{array}$ \\
\hline Mata Ciliar & Brazil & Wetland around bodies of water \\
\hline Mata ripária/ Mata de galeria & Brazil & Periodically flooded forest along rivers. \\
\hline Mata turfosa/paludosa & Southeast/ South & $\begin{array}{l}\text { It is characterized by a very particular floristic and } \\
\text { structure, differentiating itself from other forest formations } \\
\text { by its species capable of germinating and growing under } \\
\text { conditions of water saturation. }\end{array}$ \\
\hline Nascente/ Olho d'água & Brazil & $\begin{array}{l}\text { Areas for discharging water from groundwater or } \\
\text { subsurface water. }\end{array}$ \\
\hline Pântano & Brazil & A specific name for waterlogged areas. \\
\hline Restinga & Coastal área & $\begin{array}{l}\text { Bodies of shallow water and swamps between dunes on the } \\
\text { coast, outcropping groundwater }\end{array}$ \\
\hline Turfeira & South Brazil & $\begin{array}{l}\text { Small humid areas located in high altitude areas or on the } \\
\text { coastal plain with a high concentration of decomposing } \\
\text { organic matter and low } \mathrm{pH} \text { (acidic waters). }\end{array}$ \\
\hline Vargem & Brazil & Any type of periodically flooded area. \\
\hline Varjão & Mato Grosso, Tocantins, Goiás & Very large floodplain in savanna areas. \\
\hline Várzea & Central Amazon & $\begin{array}{l}\text { Floodable area along white water rivers of Andean origin, } \\
\text { rich in nutrients. }\end{array}$ \\
\hline Várzea & Other regions & Any type of periodically flooded area. \\
\hline Vereda & Brazilian cerrado & $\begin{array}{l}\text { Permanently humid area, covered by grassy herbaceous } \\
\text { vegetation. }\end{array}$ \\
\hline
\end{tabular}

Source: adapted from Junk et al. (2015).

Concerning Brazilian legislation there are still gaps related to this ecosystem. Its definition in the Forest Code excludes permanent Wetlands and does not clarify whether wetlands are only those flooded by watercourses (Siman Gomes \& Magalhães Junior, 2017), defining it as wetlands and land surfaces flooded natural and periodically, originally covered by forests or other forms of vegetation adapted to flooding (BRASIL, 2012). Wetlands can be classified according to their biological, ecological, physical, chemical, hydrological, or geomorphological attributes. Understanding the objectives and grouping the wetlands into similar units is essential to have a better description, assessment, and comparison of the wetlands 
for research and development of conservation programs and environmental impact assessment (Siman Gomes \& Magalhães Junior, 2018).

\section{Wetland Classification Systems in Brazil}

There are several instruments used for the classification of wetlands internationally. When classified in systems there are two trends, horizontal and vertical (hierarchical). Horizontal divide habitats into classes or types, while hierarchical are separate into levels, from general to specific characteristics (Siman Gomes \& Magalhães Junior, 2018). According to Junk $e t$ al. (2021), the parameters used to classify these habitats should address the specific, well-defined characteristics of each macrohabitat, hence, allowing the establishment of a databank with the necessary information.

In Brazil, institutions such as the National Institute of Wetlands (INAU) and the laboratory of ecology and conservation of aquatic ecosystems at the University of Valley of Rio dos Sinos (UNISINOS), carried out research to delimit and classify some of the large wetlands and their main habitats (Junk et al., 2013), however, these works are presented only from an ecological perspective, not incorporating geomorphological criteria. Because of the lack scientifically based classification system in Brazil, Maltchik et al. (2004), proposed the first hierarchical classification of wetland areas in the Rio Grande do Sul, presenting five levels: System, subsystem, type, class, and subclass. In 2012, Junk et al. (2012), through INAU, proposed a system for the entire Brazilian territory, to assist in the formation of a national wetland policy. It was based on three hierarchical levels: systems, units defined by hydrological factors (Subsystem, orders, and suborders) and units defined by higher plants (Class, subclass, and macro habitats).

Therefore, the Brazilian classification proposal does not incorporate geomorphological criteria or hydrogeomorphological classes (HGM), however, Junk et al. (2015), evaluate that these parameters are more useful from a scientific point of view, with no contribution to the political discussion in the management of Brazilian wetlands.

Brazil, although it has some classification systems, is weakened, since some regions remain absent, as is the case of Minas Gerais, where a classification system for Wetlands has not yet been conceived (Siman Gomes \& Magalhães Junior, 2018).

\section{Floristic composition in wetlands}

The areas subject to flooding occur predominantly on the shores of rivers and lakes, or outcrops of the groundwater (Silva et al., 2007), and their floristic pattern is determined by the climate, edaphic factors, surrounding vegetation as a source of propagule (Rodrigues \& Shepherd, 2000), anthropic actions and periodicity, duration and depth of flooding (Junk, 1993).

Pantanal is the largest tropical wetland in the world and the most important in Brazil. According to Pott et al. (2011), considering only the Pantanal plain there are approximately 2000 listed species of local flora, most belonging to the Fabaceae (240), Poaceae (212) and Malvaceae (98), with emphasis on the genera Paspalum (35), Cyperus (29) and Ipomoea (24).

Swampy forests are those that remain permanently flooded, being, according to Teixeira and Assis (2011), environments that have low species diversity and high local densities. Silva et al. (2007), characterize the floristic composition of these areas as homogeneous. The lower number of species in the swampy forests can be explained by the more selective, homogeneous, and stable environment, with constant flooding throughout the year (Marques et al., 2003). Table 2 shows the main families found in these environments, according to some surveys. 
Table 2: Families found in swampy forests in Minas Gerais (MG) and coastal regions of Brazil.

\begin{tabular}{|c|c|c|c|}
\hline Study area & $\begin{array}{cc}\text { Number } & \text { of } \\
\text { identified individuals } & \end{array}$ & Main families & Author \\
\hline $\begin{array}{l}\text { Swampy forest in the } \\
\text { south of } \mathrm{MG}\end{array}$ & $\begin{array}{l}110 \text { species } \\
50 \text { families }\end{array}$ & $\begin{array}{l}\text { Myrtaceae } \\
\text { Lauraceae }\end{array}$ & Loures et al., 2007 \\
\hline Swampy habitat in $\mathrm{MG}$ & $\begin{array}{l}99 \text { species } \\
35 \text { families }\end{array}$ & $\begin{array}{l}\text { Fabaceae } \\
\text { Myrtaceae } \\
\text { Lauraceae }\end{array}$ & Rocha et al., 2005 \\
\hline $\begin{array}{l}\text { Swanpy restinga forest in } \\
\text { the coastal plain of } \\
\text { southern brazil }\end{array}$ & $\begin{array}{l}38 \text { species } \\
22 \text { families }\end{array}$ & $\begin{array}{l}\text { Myrtaceae } \\
\text { Meliaceae }\end{array}$ & Santos-Junior et al., 2015 \\
\hline
\end{tabular}

Source: Authors (2022).

Alluvial forests, on the other hand, are vegetations subject to temporary flooding (Silva et al., 2007), these environments are distributed over the most different areas of the country, presenting remarkable compositions of biodiversity (Ab'saber, 2001). Table 3 indicates the families that stand out in the floristic composition of alluvial areas in some studies.

Table 3: Families found in alluvial forest in Brazil.

\begin{tabular}{|c|c|c|}
\hline Study area & Main families & Authors \\
\hline $\begin{array}{l}\text { Alluvial forests of southern and } \\
\text { southeastern Brazil }\end{array}$ & $\begin{array}{l}\text { Myrtaceae } \\
\text { Fabaceae }\end{array}$ & Silva et al., 2007 \\
\hline Paraíba do Sul, São Paulo, Brazil & $\begin{array}{l}\text { Myrtaceae } \\
\text { Fabaceae }\end{array}$ & D’Orázio and Catharino, 2013 \\
\hline Survey of the state of São Paulo & $\begin{array}{l}\text { Fabaceae } \\
\text { Myrtaceae } \\
\text { Rubiaceae }\end{array}$ & $\begin{array}{l}\text { Bertoni and Martins, } 1987 \\
\text { Bertani et al., } 2001 \\
\text { Teixeira and Assis, } 2005 \\
\text { Aquino, } 2006 \\
\text { Teixeira e Assis, } 2009\end{array}$ \\
\hline
\end{tabular}

Fonte: Autors (2021).

Riverside is another type of flooded environment, with a characteristic vegetal formation associated with water bodies (Oliveira-Filho, 1994), being considered areas that have an important role as corridors of plant and animal gene flow (Marinho Filho and Gastal, 2004). A floristic study carried out by Lacerda et al. (2010), in riverside areas of the caatinga, indicated a total of 91 species being Fabaceae, Euphorbiaceae, and Rubiaceae the families with the largest number of individuals and genera. The authors found that the greatest floristic identity is mainly related to the geographical distance and the characteristics of land use.

Considering the impacts of global climate change, the importance of wetlands tends to increase, making studies on the characterization of these ecosystems increasingly necessary.

\section{Legumes in wetlands}

Leguminosae (Fabaceae) is the third-largest family of Angiosperms, including about 760 genera and 19,500 species (Yahara et al., 2013), covering a great diversity of growth patterns (Doyle and Luckow, 2003). The height and duration of the periodic flooding induce the appearance of changes in the ecophysiological behavior of trees that colonize flooded areas, making it possible to adapt to conditions of oxygen scarcity for long periods (Wittmann et al., 2006). 
These tree species survive in a dormant state and may also show vigorous growth in the flooded phase (Parolin et al., 2004). However, legumes are generally sensitive to flooding, making it a limiting factor for their growth (Loureiro et al., 1998). Table 4 shows the main legume species found in wetlands in the south and southeast regions of the country.

Table 4: Legumes in wetlands in the south and southeast regions of Brazil.

\begin{tabular}{|c|c|}
\hline Species & Authors \\
\hline Acacia polyphylla $\mathrm{DC}$ & Silva et al., 2007; Campos and Landgraf, 2001 \\
\hline Apuleia leiocarpa (Vogel) Macbr & Silva et al., 2007 \\
\hline Copaifera langsdorffii Desf & Silva et al., 2007; Campos and Landgraf, 2001 \\
\hline Dalbergia frutescens (Vell.) Britton & Silva et al., 2007 \\
\hline Dalbergia miscolobium Benth & Campos and Landgraf, 2001 \\
\hline Erythrina falcata Benth & Silva et al., 2007; Loures et al., 2007 \\
\hline Inga marginata Willd & Silva et al., 2007 \\
\hline Inga uruguensis Hooker at Arnott & Campos and Landgraf, 2001 \\
\hline Inga vulpine Mart ex. O. Benth & Loures et al., 2007 \\
\hline Inga sp. Hooker at Arnott & Campos and Landgraf, 2001 \\
\hline Inga vera Willd & Silva et al., 2007 \\
\hline Lonchocarpus guillemineaus (Tul.) Malme & Loures et al., 2007 \\
\hline Lonchocarpus muehlbergianus Hassl & Campos and Landgraf, 2001 \\
\hline Machaerium hirtum (Vell) Stellfeld & Silva et al., 2007 \\
\hline Machaerium minutiflorum & Loures et al., 2007; Silva et al., 2007 \\
\hline Machaerium nyctitans (Vell.) Benth & Loures et al., 2007 \\
\hline Machaerium paraguariense Hassl & Silva et al., 2007 \\
\hline Parapiptadenia rígida (Benth) Brenan & Silva et al., 2007; Campos and Landgraf, 2001 \\
\hline Peltogyne angustiflora Ducke & Campos and Landgraf, 2001 \\
\hline Platycyamus regnelli Vog. & Campos and Landgraf, 2001 \\
\hline Pterocarpus cidacens Vog. & Campos and Landgraf, 2001 \\
\hline Sclerolobium sp. & Campos and Landgraf, 2001 \\
\hline Sweetia fruticosa Spreng & Campos and Landgraf, 2001 \\
\hline
\end{tabular}

Fonte: Autors (2021).

\section{Effects of flooding on soil and plants}

Flooding interferes with a series of physical-chemical and biological processes, deeply influencing soil quality. Among the changes, the following stand out: decreased gas exchange between the soil and the air; accumulation of gases such as $\mathrm{N}_{2}, \mathrm{CO}_{2}$ and $\mathrm{H}_{2}$, the production of hydrocarbons, phenolic compounds, alcohols, and volatile fatty acids, due to anaerobiosis; increase in $\mathrm{pH}$ in acidic soils and its reduction in alkalis, and a significant decrease in redox potential (Ponnamperuma, 1984; Gambrell et al., 1991).

The excess of water in the soil, resulting from permanent or temporary flooding, influences the species composition (Jackson and Colmer, 2005), and the stress imposed by water saturation in the soil has a highly selective character (Medri et al., 2012). According to Joly (1991), in most species, success for survival is related to morphological, physiological, and anatomical adaptations. 
Physiological adaptations in response to flooding consist of greater stomatal resistance, drop-in photosynthesis, and hydraulic conductance of the root, in addition to reduced translocation of photoassimilates (Striker, 2012 and Parent et al., 2008; Kolowski, 1997). Regarding morphological or structural adaptations, there is the formation of lenticels, aerenchyma, adventitious roots, pneumatophore, sapopemas, biological nitrogen fixation, and others (Parolin, 2012).

Also noteworthy for species underwater saturation conditions are phenological and reproductive adaptations, the former being related to leaf loss, fruit ripening, and seed release, and the latter associated with submersion tolerance, seed dormancy, and immediate germination (Parolin, 2012; Kolowski, 1997).

Pires et al. (2002), evaluating the effects of flooding on the morphophysiological characteristics of soybeans, observed that the main changes were in the roots, where was noted the death of the main root, the growth of lateral roots, and the appearance of adventitious roots, in addition to the decline of the levels of nutrients in the leaves.

\section{Biological Nitrogen Fixation in wetlands}

Nitrogen, even though it is one of the elements in greatest concentration in the atmosphere (78\%), is found in a form not available $\left(\mathrm{N}_{2}\right)$ for most living beings, including plants. $\mathrm{N}_{2}$-fixing bacteria, known as diazotrophic bacteria, can fix $\mathrm{N}_{2}$ directly from the atmosphere through the biological nitrogen fixation process (BNF). (Cleveland et al., 1999; Boddey et al., 2000).

Plants in symbiosis with diazotrophic bacteria can occupy different ecosystems, adapting to the wide variety of environmental stress. Some species of actinorhizal plants are very well adapted to wetlands, arid regions, contaminated soils, extreme $\mathrm{pH}$ and high salinity, and, due to these properties, some of these plants are pioneers that colonize disturbed areas (Santi et al., 2013). However, soil flooding impairs the nodulation of legumes and inhibits $\mathrm{N}_{2}$ fixation in previously formed nodules (Jackson, 1985).

The BNF process is closely related to edaphoclimatic factors, and wetlands are often subject to annual net nitrogen losses via leaching and are therefore largely dependent on the biological fixation process to ensure the entry of $\mathrm{N}$ into the system (Loureiro et al., 1998). Therefore, as highlighted by Hu et al. (2021), nitrogen is a common limiting nutrient for plant yield in wetlands. Consequently, most legumes that associate with diazotrophic bacteria in flooded regions have developed additional mechanisms that increase the supply of oxygen to their nodules, thus maintaining the capacity to fix nitrogen (Loureiro et al., 1998).

Legumes in flood conditions may have a limited supply of $\mathrm{O}_{2}$ for root nodules. In these environments, according to Ladha et al. (1992), stem nodulation is an advantage. Loureiro (1994), states that the stem nodules receive oxygen via aerenchyma, which allows the diffusion of gases. James et al. (2001), studying flooding-tolerant legume symbioses from the Brazilian Pantanal, observed nodules on the stem of Discolobium leptophyllum.

Krishnam et al. (2019), observed that the nodules of Sesbania herbacea grown in flooded soils were larger and more numerous concerning the ones of plants grown in dry soils. The same effect was seen by Kanu and Dakora (2015), in a study with Psoralea pinnata (L.), which in flooded areas presented nodules with greater area and volume when compared to nonflooded regions. These authors also observed that the nodules had six components: lenticels, periderm, cortex (internal, middle, and external), and infection by bacteria in the central region of the spinal cord.

\section{Final Considerations}

Although wetlands represent about $20 \%$ of Brazilian territory, these ecosystems are unprotected by law, mainly due to differences in their concepts and classification criteria. Wetlands are present in all biomes of the country. However, some states 
still lack a specific classification system that serves as a basis to ensure the preservation and maintenance of these environments.

Studies focused on these ecosystems are essential given the importance of environmental services, which have immeasurable value and ensure the sustainability of processes. The relationship between rhizobium and leguminous plants has been studied in the most diverse environments. Therefore, for wetlands, little is known about this process. The biological nitrogen fixation is considered the main mean of entry of nitrogen into these systems being so, knowing and understanding the adaptive strategies and identifying the species involved is necessary for the maintenance of biodiversity and preparation of management and conservation programs for wetlands.

In a nutshell, further studies are needed for Brazil to create more effective environmental laws, and to encourage research related to the subject and develop specific classification systems for the states to comply with the agreement signed by the Ramsar Convention. In addition, future works aiming to understand how plants and microorganisms adapt in those ecosystems are essential to create public awareness about the importance of conservating these areas.

\section{Acknowledgments}

To CAPES/PROSUP and UNIFENAS for the financial support and scholarship.

\section{References}

Ab'saber AN. (2001) O suporte ecológico das florestas beiradeiras (ciliares), p. 15 - 25. In: Rodrigues RR, Leitão Filho HDEF (orgs.). Matas Ciliares: conservação e recuperação. (2a ed.), Editora da Universidade de São Paulo: Fapesp. 320p.

Aquino C. (2006). Avaliação de três formas de enriquecimento em área ciliar revegetada junto ao rio Mogi-Guaçu, SP. Dissertação (Mestrado Ciências Biologicas - Biologia Vegetal), Universidade Estadual Paulista "Júlio de Mesquita Filho", Rio Claro. 139p.

Bertani, D. F. et al. (2001). Análise da heterogeneidade florística e estrutural em uma floresta ribeirinha. Revista Brasileira de Botânica, $24,11-23$.

Bertoni, D. W., \& Martins, F. R. (1987). Composição florística de uma floresta ripária na Reserva Estadual de Porto Ferreira, SP. Acta Botanica Brasilica, 1, $17-26$.

Boddey, R. M. et al. (2000) Use of the $15 \mathrm{~N}$ natural abundance technique to quantify biological nitrogen fixation by woody perennials. Nutrient Cycling in Agroecosystems, 57, 235-270.

Brasil (2012). Lei nº12.651, de 25 de maio de 2012. Código Florestal. <http://www.planalto.gov.br/ccivil_03/_ato2011-2014/2012/lei/112651.htm>.

Brasil, M. S. et al. (2016). Influence of flood áreas on the number of diazotrophic bacteria from pasture grasses. Applied Ecology and Environmental Sciences. 4(4), 84-88.

Campos, J.C., Landgraf, P.RC. (2001). Análise de regeneração natural de espécies florestais em matas ciliares de acordo com a distância a margem do lago. Ciência Florestal, 11(2), 143-151.

Cassetari, A. S. (2011). Diversidade de bactérias diazotróficas nodulíferas na Mata Atlântica. Dissertação (Mestrado em Ciências - Solos e Nutrição de Plantas), Universidade de São Paulo Escola Superior de Agricultura "Luis de Queiroz", Piarcicaba. 96p.

Cleveland, C. C. et al. (1999). Global patterns of terrestrial biological nitrogen (N2) fixation in natural ecosystems. Global Biogeochemical Cycles, 13, 623645 .

Costanza, R. et al. (2014). Changes in the global value of ecosystem services. Global Environmental Change, 26, $152-158$.

D'orazio, F. A. E., \& Catharino, E. L. M. (2013). Estrutura Florística de dois fragmentos de florestas aluviais no Vale do rio Paraíba do Sul, SP, Brasil. Hoehnea, 40 (3), 567-582.

Doyle, J. J., \& Lockow, M. A. (2003). The Rest of the Iceberg. Legume Diversity and Evolution in a Phylogenetic Context. Plant Physiology, 131, 900-9103.

Gambrell, R. P., Delaune, R. D., Patrick, J. W. H. (1991). Redox processes in soils following oxygen depletion., p.101-117. In: Jackson MB, Davies DD, Lambers H. (orgs.). Plant life under oxygen deprivation: ecology, physiology and biochemistry, SPB Academic Publishing, The Hague. 396p

Hu, M. et al. (2021). Low-level saltwater intrusion alters soil diazotrophic community structure in a subtropical estuarine wetland. Applied Soil Ecology, 164.

Jackson, M. B. (1985). Ethylene and responses of plants to soil waterlogging and submergene. Annual Reviews of plant Physiology, 36, 145-174.

Jackson, M. B., \& Colmer, T. D. (2005). Response and Adaptation by Plants to Flooding Stress. Annals of Botany, 96, 501-505. 
Research, Society and Development, v. 11, n. 2, e40911225787, 2022

(CC BY 4.0) | ISSN 2525-3409 | DOI: http://dx.doi.org/10.33448/rsd-v11i2.25787

James, E. N. K. et al. (2001). Flooding-tolerant legume symbioses from the Brazilian Pantanal. New Phytology, 150, 723-738.

Junk, W. J. (1993). Wetlands of tropical South America, p. 679-739. In: Whigham D, Hejný S, Dykyjová D. (orgs.). Wetlands of the world In: Inventory, ecology and management, Dr. W. Junk Publishing, Boston. 768p.

Junk, W., Bayley, P., \& Sparks, R. (2011). The flood pulse concept in river-floodplain systems: A classification of major naturally-occurring Amazonian lowland wetlands. Wetlands, 31(4), 623-640.

Junk, W. J. et al. (2012). A classification of major natural habitats of Amazonian white water river floodplains (várzeas). Wetlands Ecology and Management, 20(5), 461-4752.

Junk, W. J. et al. (2013). Brazilian wetlands: Definition, delineation and classification for research, sustainable management and protection. Aquatic Conservation: Marine and Freshwater Environments, 24(1), 5-22.

Junk, W. J. et al. (2015). Classificação e Delineamento das Áreas Úmidas Brasileiras e de seus Macrohabitats. Parte I: Definição e Classificação das Áreas Úmidas (AUs) Brasileiras: Base Científica para uma Nova Política de Proteção e Manejo Sustentável, 55p. In: Cunha CN, Piedade MTF, Junk WJ. Classificação e delineamento das áreas úmidas brasileiras e de seus macrohabitats. Cuiabá: EdUFMT. 165p.

Junk, W. J. et al. Macrohabitat classification of wetlands as a powerful tool for management and protection: The example of the Paraná River floodplain, Brazil. (2021). Ecohydrology \& Hydrobiology, 21, 411-424.

Joly, C. A. (1991). Flooding tolerance in tropical trees, p.23-34. In: Jackson MB, Daves V, Lambers H. (orgs.). Plant life under oxygen stress. Netherlands, SPB Academic Publishing, The Hague. 426p.

Kanu, S. A., \& Dakora, F. D. (2015). Symbiotic functioning, structural adaptation, and subcellular organization of root nodules from Psoralea pinnata (L.) plants grown naturally under wetland and upland conditions in the Cape Fynbos of South Africa. Protoplasma, 254(1), 137-145.

Kozlowski, T. T. (1997). Responses of woody plants to flooding and salinity. Tree physiology monograph no. 1. Victoria: Heron Publishing, 1, 1-29.

Krishnan, H. B. et al. (2019). Biochemical and Anatomical Investigation of Sesbania herbacea (Mill.) McVaugh Nodules Grown under Flooded and NonFlooded Conditions. International Journal of Molecular Sciences, 20(8), 1824.

Lacerda, A. V. (2010). Floresta arbustiva-arbórea de três áreas ribeirinhas no semiárido paraibano, Brasil. Biotaneotropica, 10(4), 275-284.

Ladha, J., Pareek, R., \& Becker, M. (1992). Stem-nodulating legume-Rhizobium symbiosis and its agronomic use in lowland rice. Advances in Soil Science, Springer: New York, NY, USA, 20, 147-192.

Loureiro, M. F., James, E. K., \& Franco, A. A. (1998). Nitrogen fixation by legumes in flooded regions. Oecologia Brasiliensis, 4, 191-219.

Loureiro, M. F. et al. (1994). Nitrogen-fixing stem nodules of the legume, Discolobium pulchellum Benth. New Phytologist, 128, $283-295$.

Loures, L. et al. (2007). Florística, estrutura e características do solo de um fragmento de floresta paludosa no sudeste do Brasil. Acta Bototanica Brasilia. 21(4), 885-896.

Maltchik, L. et al. (2004). Wetlands of Rio Grande do Sul, Brazil: A classification with emphasis on plant communities. Acta Limnologica Brasiliensia, 16(2), 137-151.

Marinho-Filho, J., \& Gastal, M. L. (2004). Mamíferos das matas ciliares dos cerrados do Brasil Central, p. 209-221. In: Matas ciliares: conservação e recuperação. Rodrigues RR, Leitão Filho HF. (orgs.). EDUSP/FAPESP, São Paulo. 320p.

Marques, M. C. M., Silva, S. M., \& Salino, A. (2003). Florística e estrutura do componente arbustivo-arbóreo de uma floresta higrófila da bacia do rio JacaréPepira, SP, Brasil. Acta Botanica Brasilica, 17, 495-506.

Medri C. et al. (2012). O alagamento do solo afeta a sobrevivência, o crescimento e o metabolismo de Aegiphila sellowiana Cham. (Lamiaceae)?. Semina: Ciências Biológicas e da Saúde, 33(1), 123-134.

Mitsch, W. J., \& Gosselink, J. G. (2000). Wetlands, 3rd ed. Wiley, 920p.

Neori, A., \& Agami, M. (2017). The Functioning of Rhizosphere Biota in Wetlands - a Review. Wetlands, 37(4), 615-633.

Oliveira-Filho, A. T. (1994). Estudos ecológicos da vegetação como subsídios para programas de revegetação com espécies nativas: Uma proposta metodológica. Cerne, 1, 64-72.

Parent, C. et al. (2008). An overview of plant responses to soil watterlogging. Plant Stress, 2(1): 20-27, 2008.

Parolin, P. et al. (2004). Central Amazon floodplain forests: tree survival in a pulsing system. The Botanical Review, 70(3), 357-380.

Parolin P. (2012). Diversity of adaptations to flooding in trees of Amazonian floodplains. Pesquisas-Botânica, 63: 7-28.

Ponnamperuma, F.N. (1984). Effects of flooding on soils, p.9-45. In: Kozlowski TT (org.). Flooding and plant growth. Academic Press, London. 356p.

Pott, A. et al. (2011). Plant diversity of the Pantanal wetland. Brazilian Journal of Biology, 71(1), 265-273.

Rocha, C. T. V. et al. (2005). Comunidade arbórea de um continuum entre floresta paludosa e de encosta em Coqueiral, Minas Gerais, Brasil. Revista Brasileira de Botânica, 28, 203-217. 
Research, Society and Development, v. 11, n. 2, e40911225787, 2022

(CC BY 4.0) | ISSN 2525-3409 | DOI: http://dx.doi.org/10.33448/rsd-v11i2.25787

Rodrigues, R. R., \& Shepherd, G.J. (2000). Fatores condicionantes da vegetação ciliar, p.101-107. In Rodrigues RR, Leitão Filho HF (orgs.). Matas ciliares: conservação e recuperação. Editora da Universidade de São Paulo, São Paulo. 320p.

Santi, C., Bogusz, D., \& Franche, C. (2013). Biological nitrogen fixation in non-legume plants. Annals of Botany, $111,743-767$.

Santos-Junior, R., Da Silva, J. G., \& Martins, R. (2015). Estrutura da comunidade arbórea em uma floresta paludosa de restinga na planície costeira do sul do Brasil. Revista Brasileira de Biociências, 13(2), 55-63.

Silva, A.C. et al. (2007). Comparação florística de florestas inundáveis das regiões Sudeste e Sul do Brasil. Brazilian Journal of Botany, $30(2)$, $257-269$.

Siman Gomes, C., \& Magalhaes Júnior, A.P. (2018). Sistemas de Classificação de Áreas Úmidas no Brasil e no Mundo: Panorama Atual e Importância de Critérios Hidrogeomorfológicos. Geo UERJ, (33), 1-32.

Siman Gomes, C., \& Magalhaes Júnior, A. P. (2017). Aparato conceitual sobre áreas úmidas (wetlands) no brasil: desafios e opiniões de especialistas. Boletim Goiano de Geografia (Online), 37(3), 485-508.

Striker, G.G. (2012). Flooding Stress on Plants: Anatomical, Morphological and Physiological Responses, p. 3-28. In: Mworia JK (org.). Botany, TechPublisher, Rijeka-Croatia. 238p.

Teixeira, A. P., \& Assis, M. A. (2005). Caracterização florística e fitossociológica do componente arbustivo-arbóreo de uma floresta paludosa no Município de Rio Claro (SP), Brasil. Revista Brasileira de Botânica, 28, 467-476.

Teixeira, A. P., \& Assis, M. A. (2009). Relação entre heterogeneidade ambiental e distribuição de espécies em uma floresta paludosa no município de Cristais Paulista, SP, Brasil. Acta Botanica Brasilica, 23(3), 843-853.

Teixeira, A. P., \& Assis, M. A. (2011). Floristic relationships among inland swamp forests of Southeastern and Central-Western Brazil. Revista Brasileira de Botânica 34, 91-101.

Wittmann, F. et al. (2006). Tree species composition and diversity gradients in whitewater forests across the Amazon Basin. Journal of Biogeography, 33(8), 1334-1347.

Yahara, T. et al. (2013). Global legume diversity assessment: Concepts, key indicators, and strategies. Taxon, 62(2), $249-266$. 